\title{
Magmatic underplating beneath the Rajmahal Traps: Gravity signature and derived 3-D configuration
}

\author{
A P Singh*, Niraj Kumar and Bijendra Singh \\ National Geophysical Research Institute, Uppal Road, Hyderabad 500 00\%, India \\ *e-mail: apsingh_ngri@yahoo.com_apsingh@ngri.res.in
}

The early Cretaceous thermal perturbation beneath the eastern continental margin of the Indian shield resulted in the eruption of the Rajmahal Traps. To understand the impact of the magmatic process that originated in the deep mantle on the lower crustal level of the eastern Indian shield and adjoining Bengal basin the conspicuous gravity anomalies observed over the region have been modelled integrating with available geophysical information. The 3-D gravity modelling has delineated $10-15 \mathrm{~km}$ thick high-density $\left(\rho=3.02 \mathrm{~g} / \mathrm{cm}^{3}\right)$ accreted igneous layer at the base of the crust beneath the Rajmahal Traps. Thickness of this layer varies from $16 \mathrm{~km}$ to the west of the Rajmahal towards north to about $12 \mathrm{~km}$ near Kharagpur towards south and about $18 \mathrm{~km}$ to the east of the Raniganj in the central part of the region. The greater thickness of the magmatic body beneath the central part of the region presents itself as the locus of the potential feeder channel for the Rajmahal Traps. It is suggested that the crustal accretion is the imprint of the mantle thermal perturbation, over which the eastern margin of the eastern Indian shield opened around $117 \mathrm{Ma}$ ago. The nosing of the crustal accretion in the down south suggests the possible imprint of the subsequent magmatic intrusion along the plume path.

\section{Introduction}

The Rajmahal Traps, at the junction of the Singhbhum craton towards the west and the Bengal basin towards the east, are one of the most conspicuous features on the geological map of the eastern Indian shield (figure 1). It appears that around $117 \mathrm{Ma}$ ago the earth opened along the palaeocontinental margin of eastern India and a huge amount of molten rock poured on to the land blanketing an area of about $4100 \mathrm{~km}^{2}$ (Baksi 1994). When identified subsurface correlative basalt in seismic and drilling results is considered, the Rajmahal Traps extend southward below the surface for at least $100 \mathrm{~km}$, beneath the Tertiary sediments of the Bengal basin covering an area of about 2, 00, $000 \mathrm{~km}^{2}$ (Sengupta 1966; Baksi et al 1987). The central part, with not less than 28 lava flows of 20 to $70 \mathrm{~m}$, is about $0.6 \mathrm{~km}$ thick (Klootwijk 1971; Pascoe 1975). Evidently, the event, which produced such a large amount of basaltic magma on the continental surface, must have had a profound influence on the crustal evolution including present day configuration of the continental lithosphere. Contrary to which its evolution and impact on the deep crustal configuration is a matter of speculation and debate.

It has been suggested that igneous intrusion at the base of the crust may underlie all shallow flood basalts (White and McKenzie 1989; Coffin and Eldholm 1994). According to Meissner (1986), a rising molten mantle material of a certain excess temperature diverges laterally in an area with a strong viscosity gradient. Zones of low viscosity, such as the continental lower crust and the asthenosphere, are weak and therefore act as the zones of decoupling, attracting lateral movements of intruding molten mantle material. The tangential stress between the laterally moving molten

Keywords. Rajmahal Traps; mantle plume; magmatism; crustal underplating; Bouguer anomaly. 


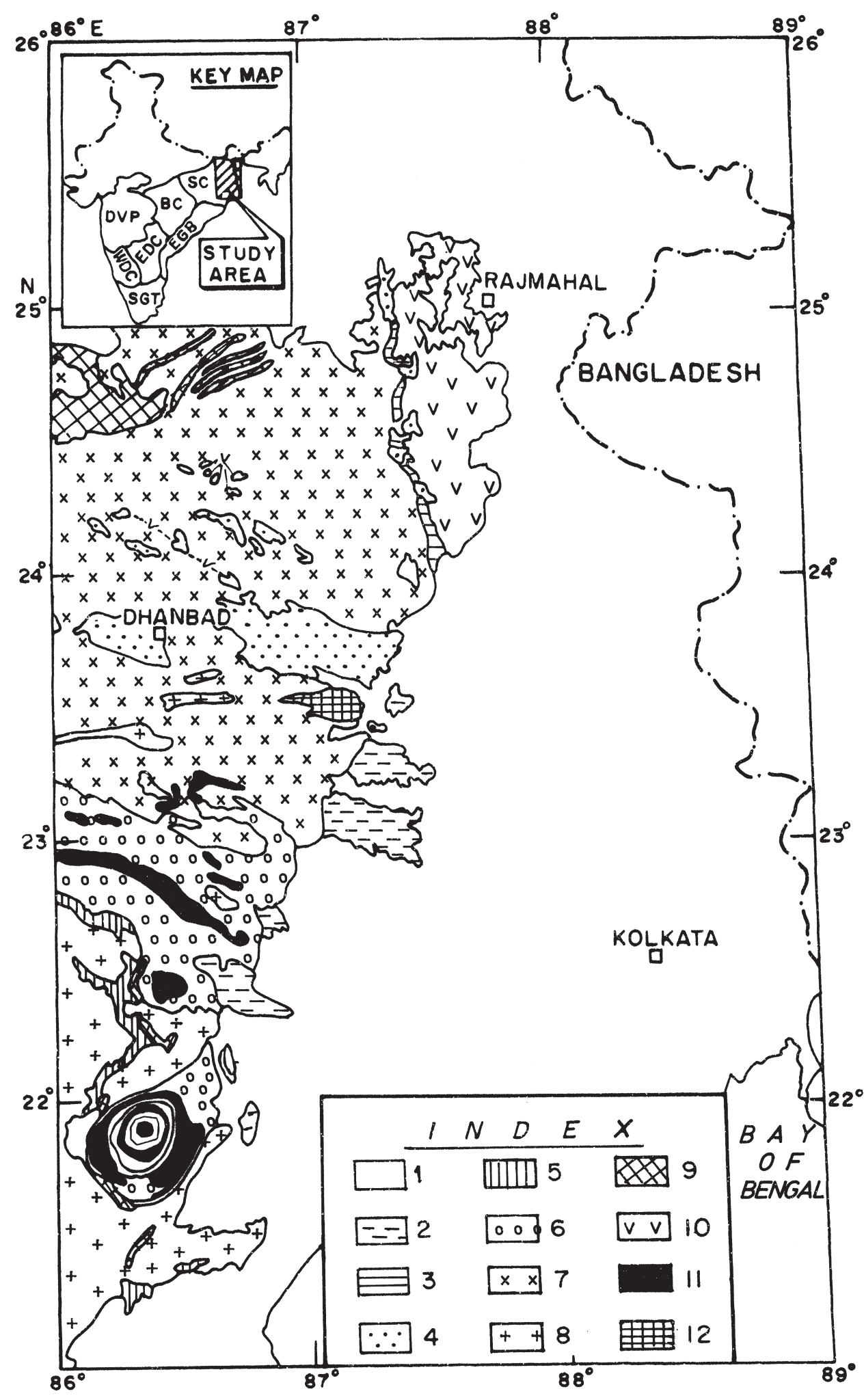

Figure 1. Generalized geology and crustal scale faulted contacts of the eastern Indian shield and the western Bengal basin. Major geological formations in the region are: (1) Quaternary sediments, (2) Laterite and bauxite, (3) Tertiary sediments, (4) Mesozoic sediments, (5) Metamorphics of Singhbhum, (6) Singhbhum Granite Gneiss, (7) Chotanagpur Gneiss complex, (8) Singhbhum Granite, (9) Chotanagpur Gneisses complex of east India, (10) Rajmahal Trap, (11) Dalma, Dhanjori and Simlipal volcanics, and (12) Gabbro and anorthosites. Abbreviations used are: BC: Bastar Craton, EGMB: Eastern Ghats Mobile Belt, EDC: Eastern Dharwar Craton, DVP: Deccan Volcanic Province, SC: Singhbhum Craton, SGT: Southern Granulite Terrain, WDC: Western Dharwar Craton. 
material and the more rigid part of the crust and mantle initiates rifting. On decompression, the molten mantle material with temperature raised to $100-200^{\circ} \mathrm{K}$ above normal generates huge amounts of melt (White and McKenzie 1989). After the extrusion has set in, according to the model, no more shear stresses are present and intrusion into the margin decreases. Cooling and contraction leave a rather homogeneous body at the base of the crust. That the density of the generated igneous rock $\left(\rho=2.99\right.$ to $\left.3.07 \mathrm{~g} / \mathrm{cm}^{3}\right)$ lies midway between that of the mantle and the crust explains why a considerable volume of the melt remains trapped as an underplated layer at the base of the crust (Furlong and Fountain 1986; White and McKenzie 1989). This density inhomogeneity in the continental crust would produce significant gravity anomalies using which Singh and Meissner (1995), Singh (1998), Singh and Mall (1998) identified the magmatic underplating at the crust-mantle boundary beneath the Deccan volcanic province and adjoining Arabian Sea (Singh 1999, 2002; Radhakrishna et al 2002). The palaeocontinental margin of the eastern Indian shield and adjoining Bengal basin encompassing the Rajmahal Traps is no exception. $V_{p}$ velocities of 7.2 to $7.5 \mathrm{~km} / \mathrm{s}$, a typical seismic signature of such magmatic layers (Furlong and Fountain 1986), are observed beneath the Bengal basin and suggested as crustal accretion due to Rajmahal volcanism (Mall et al 1999). 2-D magnetotelluric study has recently shown a uniform layer of $8 \mathrm{~km}$ thick conductive layer and interpreted as underplating at a depth of $38 \mathrm{~km}$ beneath the Proterozoic Dalma and Dhanjori volcanics in the adjoining Singhbhum craton (Bhattacharya and Shalivahan 2002). Here we report results of the gravity study carried out over the region encompassing the Rajmahal Traps indicating possible 3$\mathrm{D}$ configuration of the accreted igneous layer at the base of the crust and discuss its geodynamical implications.

\section{Geological setting}

The Archaean part of the eastern Indian shield is characterized by $3.3 \mathrm{Ga}$ old nucleus of Singhbhum Granite batholithic complex surrounded by arcuate Proterozoic belt of Chotanagpur (Sharma et al 1994). The Proterozoic Simlipal volcanics at the centre is surrounded by two major coeval volcanic dominant belts along or close to the southern margin (Dhanjori volcanics) and the other extending the northern margin of the Singhbhum craton (Dalma volcanics) with limited occurrences. Otherwise, Proterozoic to Palaeoproterozoic granite gneiss of Singhbhum and Chotanagpur constitutes the basement complex for the Bengal basin towards the east. Quaternary sediments with limited outcrops of Gondwana, Mesozoic and Tertiary sediments cover the Bengal basin. Quaternary sediments of the Purnea basin, the easternmost part of the foredeep Ganga valley, occupy the area to the north of the Rajmahal Traps. Damodar Gondwana graben towards the southwest is another characteristic feature of the region. The Rajmahal Traps of upper Jurassic to lower Cretaceous basalts with sandstone and shale as Inter-Trappeans occupy the contact zone of the eastern Indian shield and the Bengal basin.

Tectonically, the western boundary of the Rajmahal Traps is faulted one with down-throw towards the east. The eastern boundary of the Rajmahal Traps is characterized by N-S trending fault controlled basement depression that connects the Purnea basin of the Ganga valley with the Bengal basin (Tiwari and Jassal 2003). These faulted contacts together with the Damodar Gondwana graben, represent a triple junction at the mouth of the Bengal basin, whose one arm failed as a rift (Burke and Dewey 1973). The common pattern of structural style, Gondwana sedimentation, and Cretaceous volcanism, suggest that the Rajmahal Traps evolved through decompressional melting of mantle material along the then eastern continental margin of India following rifting of Gondwanaland (Mukhopadhyay et al 1986; Mukhopadhyay 2000). The rising hot and buoyant molten mantle material stretched the crust and entire lithosphere. The upper part of the crust deformed in a cold, brittle fashion separated by down-dropped valleys/grabens. The grabens may fill with up to $8 \mathrm{~km}$ of sediments and volcanic strata as they subside while forming basins (Tiwari and Jassal 2003).

\section{Nature of the Bouguer anomaly}

The Bouguer anomaly map of the Rajmahal Traps region bounded between latitudes 21 and $26^{\circ} \mathrm{N}$ and longitudes 86 and $89^{\circ} \mathrm{E}$ (NGRI 1978) along with the available seismic profiles and course of the rivers Ganga and Damodar is shown in figure 2. The region encompassing the Rajmahal Traps is well characterized by an elongated nature of relative high Bouguer anomaly (0 to $25 \mathrm{mGal}$ ) along $87^{\circ} \mathrm{E}$ in contrast to predominantly low Bouguer anomaly ( 0 to $-40 \mathrm{mGal})$ in its surroundings. This most prominent Bouguer anomaly attains its peak amplitude over the shield edge along the western margin of the Rajmahal volcanics, with an average wavelength of $100 \mathrm{~km}$ in an east-west direction. That the relative gravity high extends beyond the metamorphic-Gondwana contact encompassing an even greater part of the Rajmahal volcanics, this 


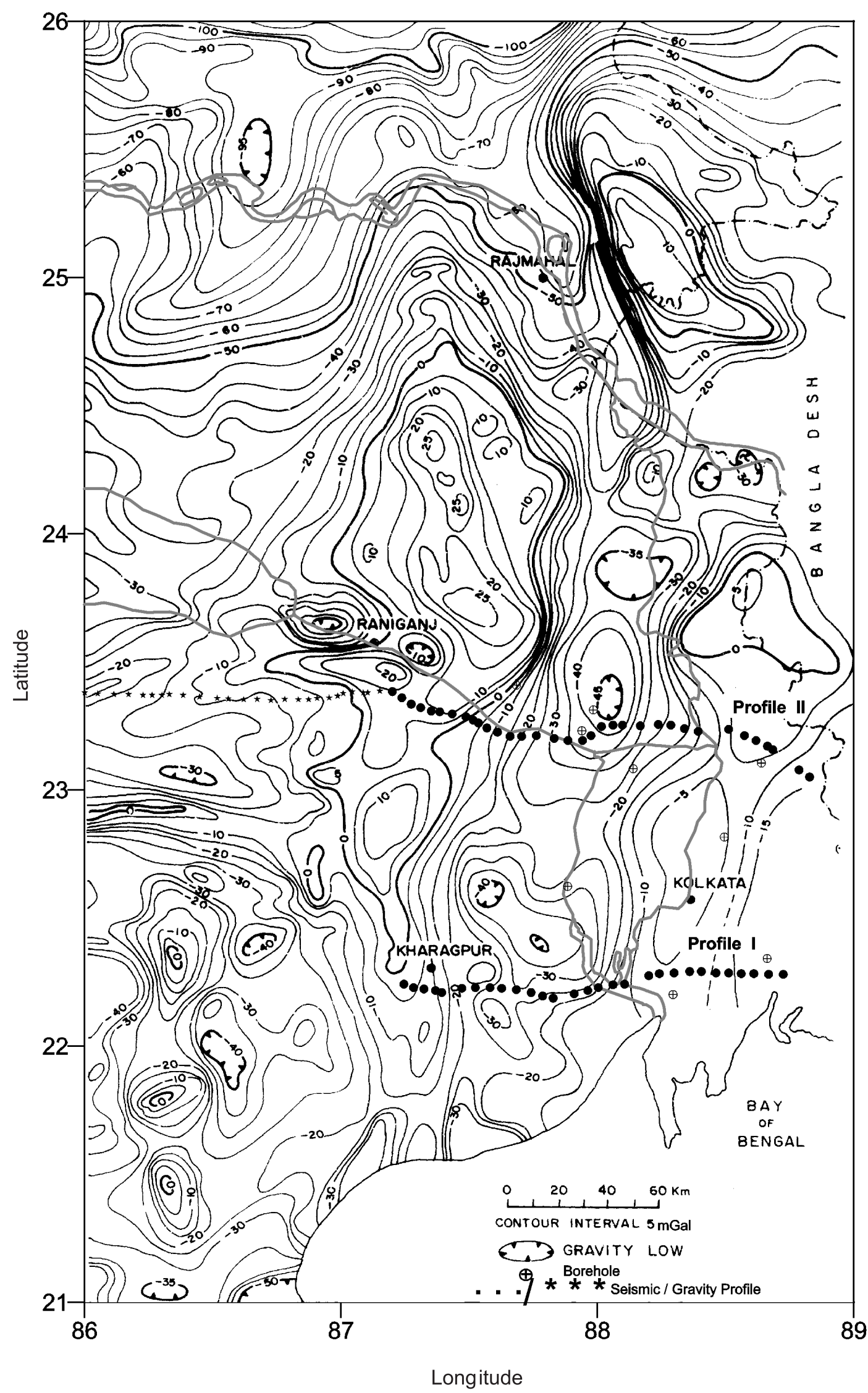

Figure 2. Bouguer anomaly map (in mGal) of the Rajmahal Traps region (NGRI, 1978) along with the course of rivers Ganga and Damodar. The map clearly shows the broad relative gravity high ( -15 to 25 mGal) over the Rajmahal Traps region and low $(-15$ to $-50 \mathrm{mGal})$ over the adjoining Bengal basin region. The two $\mathrm{E}-\mathrm{W}$ trending deep seismic profiles and the deep boreholes are shown by $\bullet$ and $\oplus$, respectively. 
long wavelength nature of the anomaly argues for a source at some deeper level; possibility at the base of the crust cannot be ruled out. A relative gravity low $(-10$ to $-20 \mathrm{mGal})$ abutting against this gravity high defines the Damodar Gondwana graben in the E-W direction. A steep gravity gradient outlines the northern limit of the high anomaly against the Gangetic foredeep gravity low $(-50$ to $-100 \mathrm{mGal}$ ) that veers southeastward around the eastern flank of the Rajmahal volcanics and areas further southeast and attributed to the fault controlled basement depression (Mukhopadhyay 2000; Tiwari and Jassal 2003). Another characteristic feature of the Bouguer anomaly map is a gravity high (0 to $10 \mathrm{mGal}$ ) over the Malda basement ridge located further east to the Rajmahal and possibly extends all along the IndiaBangladesh boarder (Tiwari and Jassal 2003). The Singhbhum granite batholith is characterized by a number of gravity highs and lows indicating compositional variations within the Singhbhum granite batholith (Verma et al 1978). The semi-circular relative gravity high $(-20$ to $0 \mathrm{mGal}$ ) over the Proterozoic Dalma volcanics around the Singhbhum granite batholith extends partly over the Quaternary sediments to the east suggesting its continuation in the Bengal basin (Verma et al 1978). The small wavelength gravity anomalies superimposed over the described highs and lows are due to the local density inhomogeneities in the region.

\section{Analysis of the gravity anomaly}

The observed Bouguer anomaly of a region (figure 2) in fact represents the total sum of gravitational attraction of all subsurface sources. Satellite derived gravity maps of the Indian region show a long wavelength anomaly centred over the Indian Ocean geoidal low whose effect varies from zero near the $25^{\circ} \mathrm{N}$ to $-48 \mathrm{mGal}$ at the southern tip of the India (Marsh 1979). Therefore, a part of the predominant negative bias, in the large wavelength Bouguer anomaly over Peninsular India, seems to be related to the density heterogeneities in the upper mantle (Verma and Satyanarayana 1990). To determine the crustal sources of the Bouguer anomaly, the component related to this subcrustal variation, equivalent to first order polynomial approximation, is removed from the observed gravity field. The relative gravity high over the Rajmahal Traps, extending over a length $300 \mathrm{~km}$ and with a width of $100 \mathrm{~km}$, provides an ideal condition for its two dimensional examination. Since the gravity modelling is inherently non-unique its integration with the wide angle seismic reflection the so called deep seismic sounding
(DSS) provides an excellent tool to quantify the deep crustal structure. The seismic depth section provides a priori information about the initial density $(\rho)$ model and $V_{p}-\rho$ relationship may be used to obtain the average density values of subsurface layers (Meissner 1986). Subsequently the information may be used for the 3-D approximation of the underplated layer, expected through the Rajmahal volcanism.

\section{Seismic information}

There are two east-west trending DSS profiles, namely (i) the Gopali-Port Canning, and (ii) the Beliator-Bangaon available in the adjoining Bengal basin that provides first hand information about the crustal configuration in the vicinity of the Rajmahal Traps (figure 3; Kaila et al 1992, 1996). These two seismic profiles, each well constrained by eight and fourteen shot points, respectively showed the basement and sub-basement crustal structure with four distinct layers in the Bengal basin. The thickness of the Quaternary sediments $\left(V_{p} \approx 2.8 \mathrm{~km} / \mathrm{s}\right)$ of the Bengal basin varies from about $0.5 \mathrm{~km}$ along the shield-basin margin to about $8 \mathrm{~km}$ towards the east. The Rajmahal Traps $\left(V_{p} \approx 4.8 \mathrm{~km} / \mathrm{s}\right)$ were found to lie over the Gondwanas $\left(V_{p} \approx 3.8 \mathrm{~km} / \mathrm{s}\right)$, which is in corroboration with the drilling results of Burdwan and Palashi wells. The crystalline basement dips towards the east reaching to a maximum depth of about $10-11 \mathrm{~km}$. A low velocity layer of about $2-3 \mathrm{~km}$ thickness $\left(V_{p} \approx 5.6-5.8 \mathrm{~km} / \mathrm{s}\right)$ has been delineated along both the profiles. Another prominent but almost horizontal mid crustal layer separating upper $\left(V_{p} \approx 6.4 \mathrm{~km} / \mathrm{s}\right)$ and lower $\left(V_{p} \approx 6.8 \mathrm{~km} / \mathrm{s}\right)$ crust lies at a depth of about $25-28 \mathrm{~km}$. In the initial seismic sections (Kaila et al 1992, 1996) Moho varies from $26-36 \mathrm{~km}$ along the profile-II and $32-34 \mathrm{~km}$ along the profile-I. No direct seismic signature of the crustal accretion at the base of the crust beneath the region was indicated in the original depth sections (Kaila et al 1992, 1996). However, a re-examination of the same data did indicate about $10 \mathrm{~km}$ thick high-velocity $\left(V_{p} \approx 7.5 \mathrm{~km} / \mathrm{s}\right)$ layer along the profile-I and about $3-5 \mathrm{~km}$ thick same layer along the profile-II and interpreted as an underplated mantle material injected by the mantle plume at the base of the crust (Mall et al 1999). Possibly, what has been assumed to be Moho in the initial DSS profiles (Kaila et al 1992, 1996) actually represents the high-velocity discontinuity where the crust is transformed into a transitional zone. The new Moho now lies at a depth of about $41-42 \mathrm{~km}$ along the profile-I and varies from $31-38 \mathrm{~km}$ along the profile-II (Mall et al 1999). 

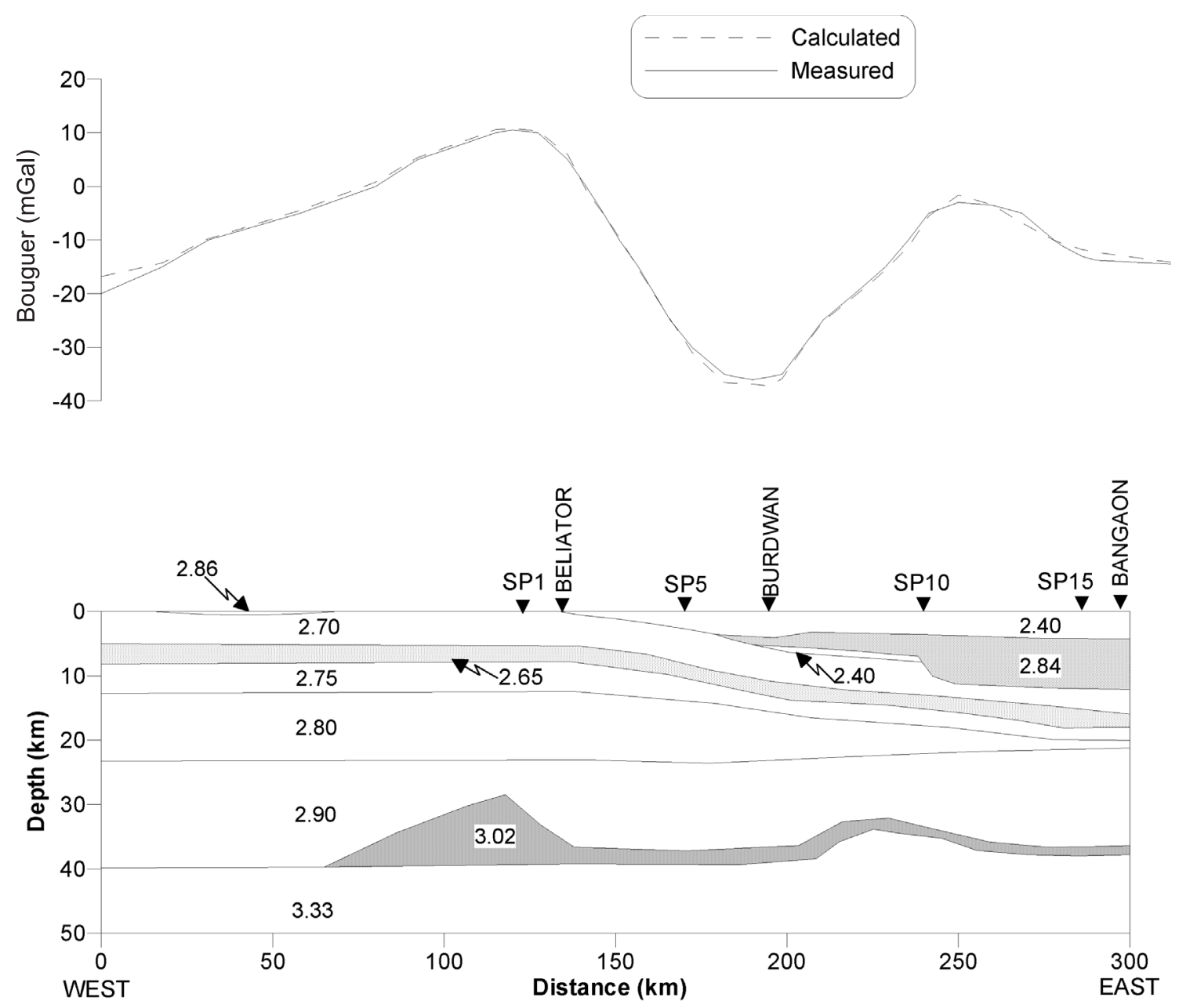

Figure 3. 2-D gravity model, partially constrained by available seismic section, along the DSS profile-II. SP is the DSS Shot Point. Densities are in $\mathrm{g} / \mathrm{cm}^{3}$.

\section{Two-dimensional gravity modelling}

The seismic profile-II of the adjoining Bengal basin, being at the centre of the present study area, is extended towards the west to cross the distal portion of the Rajmahal Traps (figure 2). The concept of 2-D interactive forward gravity modelling with a priori DSS information is then applied to get the crustal configuration of the Rajmahal Traps region. Emphasis was given more to the lower crustal parts, which are most significant for geodynamic models and where the impact of Rajmahal volcanism is most relevant. The expected undulations in the deep crustal layers are well reflected in the broad regional features observed on the gravity profile. The theoretical gravity anomalies calculated for the initial density model derived from original (Kaila et al 1992, 1996) and revised (Mall et al 1999) seismic sections are unexpectedly inconsistent to the observed gravity field. A highly warped-up Moho reaching a depth of about $26 \mathrm{~km}$ from the surface along the eastern end, as suggested by the initial DSS studies (Kaila et al 1992, 1996), produces a relatively positive gravity anomaly of a considerably higher magnitude than the observed field. Besides, the calculated gravity field values of the crustal structure with flat transitional Moho of the same thickness (Mall et al 1999), has hardly any effect on the observed Bouguer anomaly. Keeping all other parameters constant, the boundary of the transitional layer together with its density was therefore suitably adjusted to match the observed gravity anomaly. Care was, however, taken that the density $\left(3.02 \mathrm{~g} / \mathrm{cm}^{3}\right)$ and the depth of this interface remain compatible with the revised seismic sections (Mall et al 1999). The final crustal structure with varying transitional layers lying at the base of the crust that produced an optimal match between the observed and the calculated gravity anomalies is shown in figure 3 . A greater thickness of the anomalous transitional layer along shield-basin margin possibly indicates the locus of the crustal accretion beneath the Rajmahal Traps. 


\section{Three-dimensional gravity modelling}

To ascertain the 3-D configuration of the accreted igneous layer beneath the Rajmahal Traps region the gravity anomalies corrected for the Indian Ocean geoidal low needs to be further isolated from the anomalies due to the other crustal sources. Because the shallow structural features are of no interest here, their effects need to be adequately removed from the Bouguer anomaly. However, regional and residual separation of the observed gravity fields is vital but not unique in gravity interpretation. One established procedure is to separate regional and residual fields through convolution. Another common procedure is the manual operation of smoothing. These two approaches are complementary in the sense that "filtering" can be based on a few general assumptions, whereas "smoothing" is more akin to local modelling and interpretation in which more external information is integrated into the process. It has been proposed by Jacobsen (1987) to use the upward continuation as a standard suboptimum filter, which can solve a wide span of separation problems when applied to real, non-random anomalies. According to him the optimum filter for the extraction of the field associated to sources below certain depths $\left(Z_{0}\right)$ is the upward continuation to the height $\left(2 Z_{0}\right)$ above the measurement plane. A thickness of $15 \mathrm{~km}$ for the horizontal layer representing the upper crust is chosen as a compromise (Kaila et al 1992, 1996; Reddy et al 1993; Mall et al 1999) and the Bouguer anomaly corrected for the Geoid effect was then subjected to the upward continuation to a height of $30 \mathrm{~km}$ for the extraction of the field associated to sources below $15 \mathrm{~km}$ depth. The resulting Bouguer anomaly used for the 3-D approximation of the source body is shown in figure 4 .

The relative high gravity anomaly (figure 4), of about +5 mGal over the Rajmahal Traps, appears to be caused by the magmatic underplating at the base of the crust. For a detailed investigation of this filtered component of the Bouguer anomaly, the concept of interactive forward 3-D gravity modelling developed by Götze and Lahmeyer (1988) is applied. In this method the gravity effect of a homogeneous polyhedra of suitable geometry and density, constrained from the a priori information, is calculated by transforming a volume integral into a sum of line integrals. The DSS information and the correlative 2-D density modelling provided the necessary a priori information to constrain the initial 3-D density model of the underplated layer. A density of 2.99 to $3.07 \mathrm{~g} / \mathrm{cm}^{3}$ is suggested for such accreted igneous layers (Furlong and Fountain 1986; White and McKenzie 1989). An average density of $3.02 \mathrm{~g} / \mathrm{cm}^{3}$ is therefore assigned to the delineated underplated layer. Though the nature of the computed gravity values for the given a priori subsurface geometry broadly matched with the filtered Bouguer anomaly the calculated gravity values, however, did not conform well in the eastern part of the filtered Bouguer anomaly. Trusting the Moho geometry as delineated by the present 2-D modelling, we suitably modified the transitional layer to match the observed anomaly. The resulting 3-D configuration of the accreted igneous layer (figure 5) shows an undulating structure with an average height of about $10-15 \mathrm{~km}$ lying above the 36 to $38 \mathrm{~km}$ deep Moho. More than $10 \mathrm{~km}$ thick isolated centres with circular or elliptical cross-sections, probably represent the potential feeder channels for the Rajmahal Traps. The contacts between the steep-sided outward dipping inverted conical roots of the magmatic body with their host rocks are sharp, but occasional gradational contacts are also discernable. Another characteristic feature of the present 3-D density model is the deeper Moho towards the north and east of the Rajmahal Traps region. Obviously, a Moho of about 41 to $42 \mathrm{~km}$ deep beneath the northern foredeep Ganga valley is controlled by the India-Eurasia tectonics.

\section{Discussion}

The gravity modelling shows a $10-15 \mathrm{~km}$ thick high-density $\left(\rho=3.02 \mathrm{~g} / \mathrm{cm}^{3}\right)$ homogeneous but anomalous crustal layer above a depth of $38 \mathrm{~km}$ below the Rajmahal Traps. Such high-density layers are rather unusual in normal crustal structures and are often found at the crust/mantle interface in shield regions, in many active rift/graben systems and along passive volcanic continental margins (Meissner 1986). Keeping in view the outcrops of charnockite along the southern fringe of the Singhbhum craton, these rocks were considered as the most likely candidates for the high-density layer (Mukhopadhyay et al 1986). Negating the possibility for similar crustal layer beneath the Proterozoic Dalma, Dhanjori and Simlipal volcanics, Bhattacharya and Shalivahan (2002) argued in favour of magmatic underplating beneath that region. A denser lower crust with outward dipping sides along the eastern Indian shield margin was considered as the underplated mantle material at the base of the crust (Mukhopadhyay 2000). In the realm of Rajmahal magmatism we attribute the delineated high-density $\left(\rho=3.02 \mathrm{~g} / \mathrm{cm}^{3}\right)$ lower crustal layer as the igneous crustal accretion beneath the Rajmahal Traps region. The inference is compatible not only with the lower crustal accretion beneath the Deccan volcanism (Singh 2002) but also with similar observations along the passive volcanic margins all over the world (White and McKenzie 1989; Coffin and Eldholm 1994). 


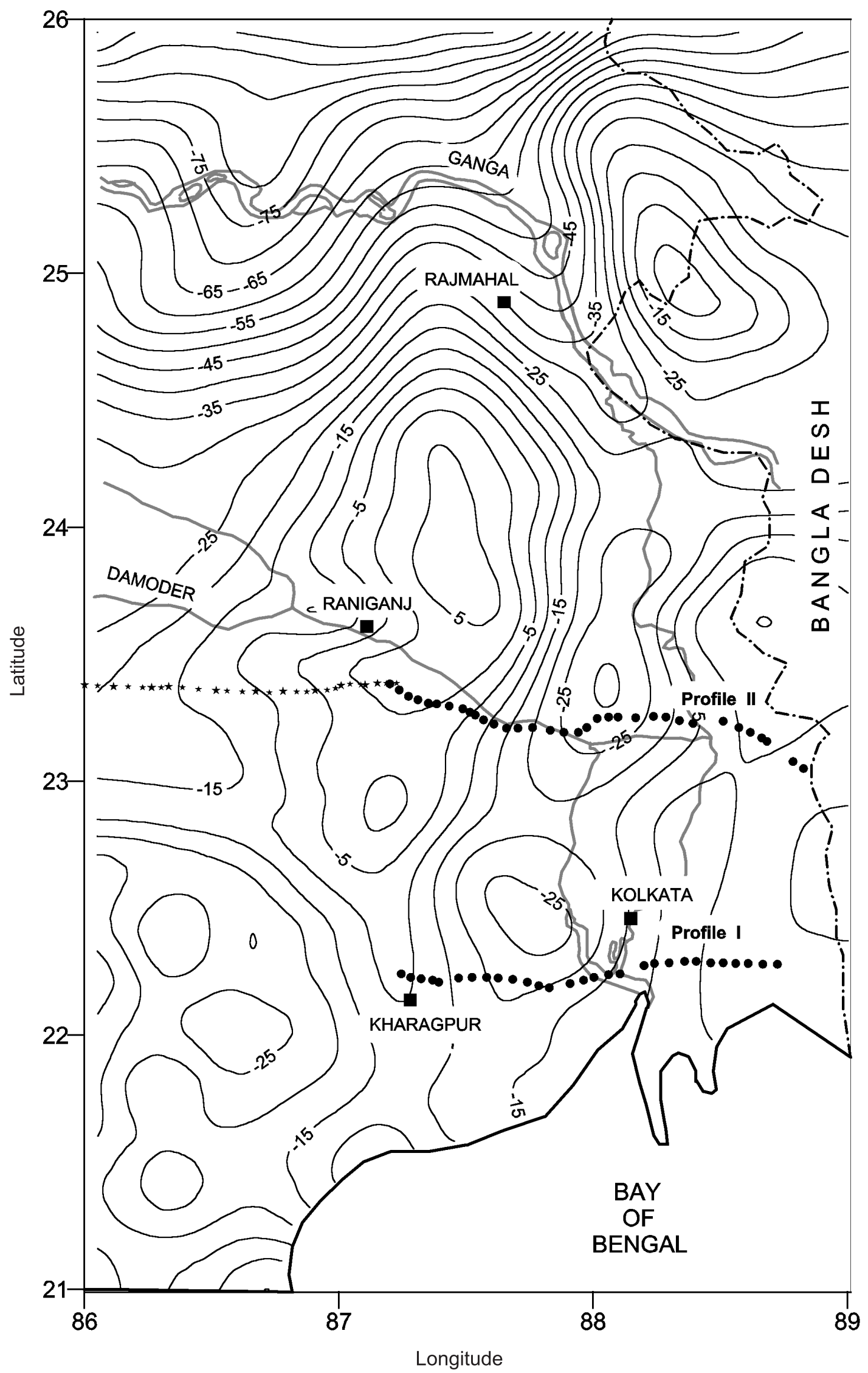

Figure 4. Filtered Bouguer anomaly map (in mGal) of the Rajmahal Traps region. The observed Bouguer anomaly (figure 2) was first corrected for the Indian Ocean Geoid and then was subjected to the upward continuation to a height of $30 \mathrm{~km}$. The course of the rivers Ganga and Damodar and the Indo-Bangladesh border are marked for ready reference. 


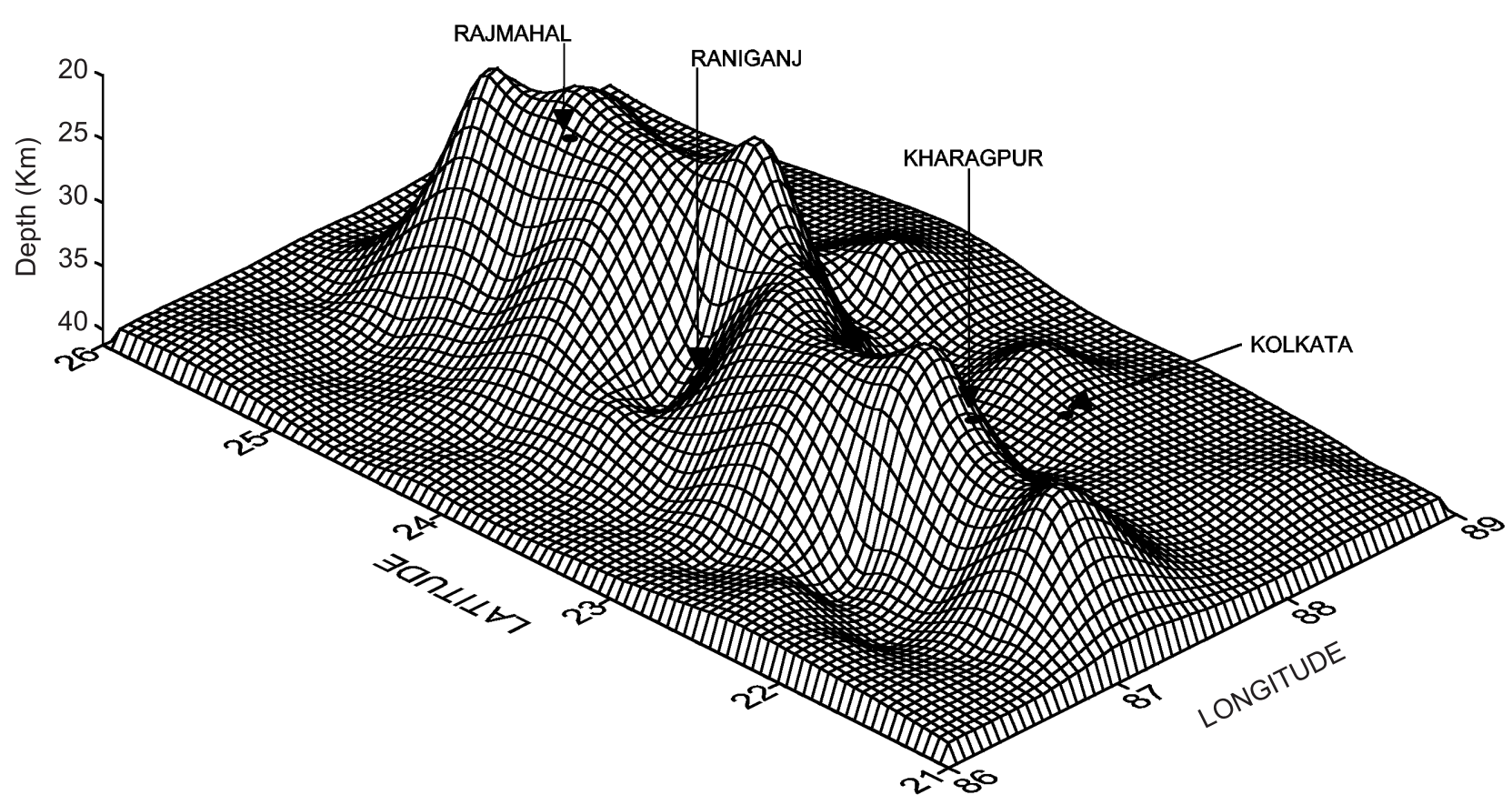

Figure 5. 3-D configuration of the accreted igneous layer beneath the Rajmahal Traps region lying over a Moho of about $38 \mathrm{~km}$ depth. The thickness of the accreted igneous layer varies from 10 to $15 \mathrm{~km}$ in the region.

Plausible explanation for the magmatic accretion includes thermal perturbation caused by decompressional melting (Anderson 2000) and/or long lived deep mantle plume models (Morgan 1981). Mukhopadhyay et al (1986) and Mukhopadhyay (2000) have stated that the Rajmahal volcanism was related to the continental rifting process, in which, the volcanism was envisioned as a "passive" response to lithospheric thinning. The inferred crustal accretion, according to them, therefore owes its origin to the rifting of the Indian shield following the Gondwanaland break-up. Contrary to which, consensus seems to be that the Rajmahal Traps originated from a hotspot (Curray and Munasinghe 1991; Muller et al 1993; Subrahmanyam et al 1999). Kent (1991) and Kent et al (1992) argued in favour of a long-lived DUPAL mantle plume beneath this sector of the Gondwanaland by assuming a plume incubation model. These two thermal instabilities probably represent the two distinct types of the hotspots causing mantle plumes in the Earth's crust (Courtillot et al 2003). Without going deep into the protected arguments of the thermal processes if we simply consider that a mantle plume supplied the molten material for the Rajmahal Traps, it must have contributed to the crustal accretion through secondary convection in a low viscosity environment of the rifted continental lithosphere.

The causative hotspot for the thermal perturbation, responsible for the evolution of the Rajmahal
Traps and/or the break-up of the Gondwanaland, is a matter of speculation and debate. Despite a number of re-constructions (Duncan and Richards 1991; Storey 1995) controversy still exists as to whether the purported plume was Crozet/Conrad rise or Kerguelen and the path was associated to $85^{\circ} \mathrm{E}$ or $90^{\circ} \mathrm{E}$ ridge, respectively (Curray et al 1982 ; Liu et al 1982; Mahoney et al 1983; Curray and Munasinghe 1991; Muller et al 1993; Baksi 1994; Subrahmanyam et al 1999). Given that the present study is confined to the continental part, the nosing of the underplated layer towards south along $87^{\circ} \mathrm{E}$ point towards probable axis of the plume path in the continental region. Further geophysical data in the oceanic part are needed for precise correlation either with $85^{\circ} \mathrm{E}$ ridge or with $90^{\circ} \mathrm{E}$ ridge, and as such we confine our interpretation to the continental segment only.

\section{Conclusions}

At the time of mantle plume outburst causing the Rajmahal Traps, the eastern palaeocontinental margin of the Indian shield was underplated by magmatic material $\left(\rho=3.02 \mathrm{~g} / \mathrm{cm}^{3}\right)$, resulting in the formation of a $10-15 \mathrm{~km}$ thick layer at the base of the crust. A greater thickness of the accreted igneous layer beneath the gravity high east of the Raniganj, presents itself as the potential feeder channel for the Rajmahal Traps. The nosing of 
inferred crustal accretion about $87^{\circ} \mathrm{E}$ longitude in the southern part suggests the possible imprint of the subsequent magmatic intrusion along the plume path.

\section{Acknowledgements}

We thank the Director, NGRI, Hyderabad for his encouragement and permission to publish this work. Thanks are also due to Dr. M Radhakrishna and two anonymous reviewers for constructive and useful suggestions, which have significantly improved the quality of the manuscript. Mr. Anish Kumar is duly acknowledged for drafting the illustrations.

\section{References}

Anderson D L 2000 The thermal state of the upper mantle: no role for mantle plumes; Geophys. Res. Lett. $\mathbf{2 7}$ $3623-3626$

Baksi A K 1994 Revised plate motions relative to the hotspots from combined Atlantic and Indian Ocean hotspot tracks: comment and reply; Geology 22 276-277

Baksi A K, Ray Barman T, Paul D K and Farrar E 1987 Widespread early Cretaceous flood basalt volcanism in eastern India: Geochemical data from the RajmahalBengal-Sylhet traps; Chem. Geol. 63 133-141

Bhattacharya B B and Shalivahan 2002 The Elecrtic Moho underneath Indian Craton; Geophys. Res. Lett. 29 (10) 141-144

Burke K and Dewey J F 1973 Plume generated triple junctions: Key indicators in applying plate tectonics to old rocks; J. Geol. 81 406-433

Coffin M F and Eldholm D 1994 Large igneous provinces: crustal structures, dimensions, and external consequences; Rev. Geophys. 32 1-36

Courtillot V, Davaille A, Besse J and Stock J 2003 Three distinct types of hotspots in the Earth's mantle; Earth Planet. Sci. Lett. 205 295-308

Curray J R, Emmel F J, Moore D G and Raitt R W 1982 Structure, tectonics and geological history of the northeastern Indian Ocean; In: Ocean Basins and Margins (eds) A E M Nairn and F G Stehli; The Indian Ocean (New York: Plenum Press) 6 399-450

Curray J R and Munasinghe T 1991 Origin of the Rajmahal Traps and the $85^{\circ} \mathrm{E}$ Ridge: Preliminary reconstructions of the trace of the Crozet hotspot; Geology 19 1237-1240

Duncan R A and Richards M A 1991 Hotspots, mantle plumes, flood basalts and true polar wander; Rev. Geophys. 29 31-50

Furlong K P and Fountain M D 1986 Continental crustal underplating: thermal considerations and seismic, petrologic consequences; J. Geophys. Res. 91 8285-8295

Götze H J and Lahmeyer B 1988 Application of threedimensional interactive modeling in gravity and magnetics; Geophysics 53 1096-1108

Jacobsen B H 1987 A case for upward continuation as a standard separation filter for potential field maps; Geophysics 52 1138-1148

Kaila K L, Reddy P R, Mall D M, Venkateswarlu N, Krishna V G and Prasad A S S S R S 1992 Crustal structure of the West Bengal basin, India, from deep seismic sounding investigations; Geophys. J. Int. 111 45-66
Kaila K L, Murthy P R, Madhava Rao N, Rao I B P, Rao P K, Sridhar A R, Murty A S N, Vijaya Rao V and Prasad B R 1996 Structure of the crystalline basement in the West Bengal basin, India, as determined from deep seismic sounding studies; Geophys. J. Int. 124 $175-188$

Kent R 1991 Lithospheric uplift in Eastern Gondwana: Evidence for a long lived mantle plume system; Geology 19 $19-23$

Kent R W, Storey M and Saunders A D 1992 Large igneous provinces: sites of plume impact or plume incubation; Geology 20 891-894

Klootwijk C T 1971 Paleomagnetism of the upper Gondwana Rajmahal traps, northeast India; Tectonophysics $\mathbf{1 2}$ 449-467

Liu C-S, Sandwell D T and Curray J R 1982 The negative gravity field over the $85^{\circ} \mathrm{E}$ Ridge; J. Geophys. Res. 87 (B9) $7673-7686$

Mahoney J J, Macdougall J D, Lugmair G W and Gopalan K 1983 Kerguelen hot spot source for Rajmahal traps and Ninetyeast Ridge; Nature 303 385-389

Mall D M, Rao V K and Reddy P R 1999 Deep sub-crustal features in the Bengal basin: Seismic signatures for plume activity; Geophys. Res. Lett. 26 2545-2548

Marsh J G 1979 Satellite derived gravity maps, section-2. In: A Geophysical Atlas for Interpretation of Satellite Derived Gravity Data. (eds) P D Lowmen Jr and H V Fray, Maryland, USA: NASA, Greenbelt

Meissner R 1986 The Continental Crust: A Geophysical Approach (New York: Academic Press) pp 426

Morgan W J 1981 Hotspot tracks and the opening of the Atlantic and Indian Oceans (ed) C Emiliani, The Sea. Vol. 7 (New York: Wiley Interscience) pp. 443-487

Mukhopadhyay M 2000 Deep crustal structure of the West Bengal basin deduced from gravity and DSS data; J. Geol. Soc. India 56 351-364

Mukhopadhyay M, Verma R K and Ashraf M H 1986 Gravity field and structures of Rajmahal hills: Examples of the Palaeo-Mesozoic continental margin in eastern India; Tectonophysics 131 353-367

Muller R D, Royer J-Y and Lawver L A 1993 Revised plate motions relative to the hotspots from combined Atlantic and Indian Ocean hotspot tracks; Geology 21 275-278

NGRI 1978 NGRI/GPH-1 to 5: Gravity Maps of India scale $1: 5,000,000$. National Geophysical Research Institute, Hyderabad, India

Pascoe E H A 1975 Manual of Geology of India and Burma, (New Delhi: Gov. of India Publ.)

Radhakrishna M, Verma R K and Purushotham A K 2002 Lithospheric structure below the eastern Arabian Sea and adjoining west coast of India based on integrated analysis of gravity and seismic data; Marine Geophy. Res. 23 25-42

Reddy P R, Venkateswarlu N, Prasad A S S S R S and Koteswara Rao P 1993 Crustal density model across West Bengal basin, India: An integrated interpretation of seismic and gravity data; Proc. Indian Acad. Sci. (Earth Planet. Sci.) 102 487-505

Sengupta S 1966 Geological and geophysical studies in western part of Bengal basin, India; American Association of Petroleum Geology Bulletin 50 1001-1017

Sharma M, Basu A R and Ray S L 1994 Sm-Nd isotopic and geochemical study of the Archaean tonalitic-amphibolite association from the eastern Indian craton; Contrib. Mineral Petrol. 117 45-55

Singh A P 1998 3-D Structure and geodynamic evolution of accreted igneous layer in the Narmada-Tapti region (India); J. Geodynamics 25 129-141 
Singh A P 1999 The deep crustal accretion beneath the Laxmi Ridge in the northeastern Arabian Sea: the plume model again; J. Geodynamics 27 611-626

Singh A P 2002 Impact of Deccan volcanism on deep crustal structure along western part of Indian mainland and adjoining Arabian Sea; Current Science $\mathbf{8 2}$ $101-110$

Singh A P and Meissner R 1995 Crustal configuration of the Narmada-Tapti region (India) from gravity studies; J. Geodynamics 20 111-127

Singh A P and Mall D M 1998 Crustal accretion beneath the Koyna coastal region (India) and Late Cretaceous geodynamics; Tectonophysics 290 285-297

Storey B C 1995 The role of mantle plumes in continental breakup: case histories from Gondwanaland; Nature $\mathbf{3 7 7}$ 301-308
Subrahmanyam C, Thakur N K, Gangadhara Rao T, Khanna R, Ramana M V and Subrahmanyam V 1999 Tectonics of the Bay of Bengal: new insights from satellite gravity and ship borne geophysical data; Earth Planet. Sci. Lett. 171 237-251

Tiwari S and Jassal G S 2003 Origin and evolution of the Garo-Rajmahal Gap; J. Geol. Soc. India 57 389-403

Verma R K and Satyanarayana 1990 Gravity field, deep seismic sounding and crust mantle structure over the Cuddapah basin and Dharwar craton of India; Tectonophysics $\mathbf{1 7 8} 337-356$

Verma R K, Mukhopadhyay M, Roy S K and Sinha R P P 1978 An analysis of gravity field over north Singhbhum; Tectonophysics $\mathbf{4 4}$ 41-63

White R S and McKenzie D P 1989 Magmatism at rift zones: the generation of volcanic continental margins and flood basalts; J. Geophys. Res. 94 7685-7729 